\title{
GLOBALISATION, THE DEVELOPMENT OF
}

CONSTITUTIONALISM AND THE INDIVIDUAL EMPLOYEE

\section{K Calitz}

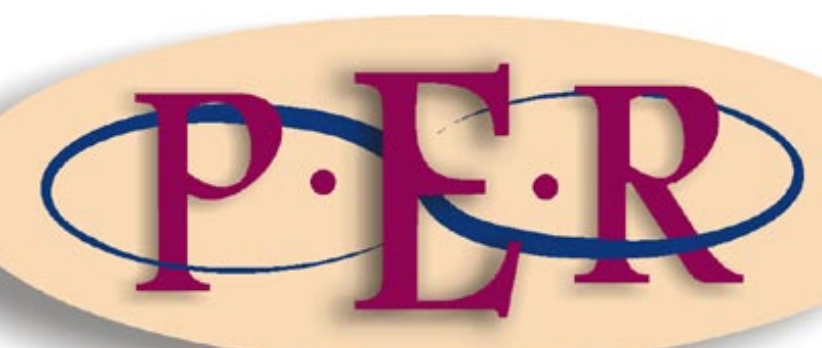

2007 Volume 2 


\section{GLOBALISATION, THE DEVELOPMENT OF CONSTITUTIONALISM AND THE INDIVIDUAL EMPLOYEE}

K Calitz*

\section{Introduction}

This article will investigate the effect of globalisation on the development of constitutionalism in South Africa, specifically in the context of the protection of employees involved in international employment contracts.

For the purpose of this article "globalisation" means the accelerated integration of economies throughout the world through trade, financial flows, the exchange of technology, information and ideas, and the movement of people. ${ }^{1}$ The main focus of the article is the phenomenon of employers and employees who move across national borders to do business and work, thereby becoming economically active in different countries.

The concept of the development of constitutionalism is a complex one with various dimensions. An important facet relates to issues with regard to the separation of powers and the curtailing of the power of the state vis-à-vis the individual. ${ }^{2}$ In this article the development of constitutionalism will be seen as the growing "pervasive normative effect" of constitutional values, ${ }^{3}$ (especially those in the Bill of Rights) that will gradually forge a just society. ${ }^{4}$

* Lecturer, University of Stellenbosch.

1 Calitz 2000 South African Journal of Economics 564-606.

2 Waluchow 2007 http://plato.stanford.edu/entries/constitutionalism/ 7 May; Cachalia et al Fundamental Rights 3.

$3 \quad$ NK v Minister of Safety and Security (2005) 26 ILJ 1205 (CC) 1213.

4 Currie and De Waal New Constitutional \& Administrative Law states: "...the South African Constitution is not confined to disciplining public power in order to protect a sphere of private activities. Instead, the 1996 Constitution seeks to direct both public and private power to achieve a substantive vision of a good society." 
The airplane crash on 5 May 2007 in Cameroon ${ }^{5}$ in which seven South Africans died, reminded us that in the globalisation era many South Africans are regularly working outside the borders of South Africa. The deceased may have been working for themselves or as employees of someone else. If they were employees they may have been working for a South African employer, an employer based in an African country, or a foreign employer who has business interests in Africa. This raises the question of how to determine which country's legal system will regulate an employment relationship with foreign aspects. This is important because labour law systems differ among countries.

There may be conflict between countries in terms of the level of protection afforded to employees. For example, in Trythall $v$ Sandoz ${ }^{6}$ the employer (a Swiss company operating in South Africa) argued that the contract should be regulated by Swiss law because it is a Swiss company and because the contract was concluded in Switzerland. In terms of Swiss law the employer could (according to evidence in this case) dismiss the employee by merely giving the required notice. On the other hand, the employee argued that as South Africa was the place of performance of the contract, South African law should apply. According to South African law the dismissal of the employee would be regarded as an unfair labour practice. According to evidence the concept of an unfair labour practice was unknown to Swiss law and would thus leave the employee without a remedy. Which legal system should regulate the contract in such circumstances? ${ }^{7}$

To answer this question, the rules of private international law (or conflict of laws) must be applied. The purpose of these rules is to ensure that justice is done between private litigants. ${ }^{8}$ Each country has its own rules of private international law and each country's courts will apply its own rules if the court is

$5 \quad$ Anon Sunday Times 1

6 Trythall v Sandoz (1994) 15 ILJ 661 (IC) 666. Hereafter Trythall.

7 In Trythall the court held that the SA legal system should regulate the contract, mainly on the ground that the contract was performed in South Africa.

8 Parry v Astral [2005] 10 BLLR 989 (LC) 998. 
seized with a matter that involves foreign elements. ${ }^{9}$ There are many similarities in the rules of private international law of different countries (especially those countries whose rules of private international law are based on Roman-Dutch law), but there are also substantial differences. The ideal is global uniformity, but this is still only an ideal. ${ }^{10}$ International Conventions ${ }^{11}$ are powerful instruments in this regard, but are also limited in that countries first have to ratify a Convention before it becomes effective.

The rules of private international law will be applied by the court seized with the matter and this will entail that a consecutive stages process ${ }^{12}$ be followed in order to establish which legal system should regulate the matter. The outcome of this process could be that another country's law will be applied by the South African court or that a foreign court will apply South African law.

\section{The process of finding the applicable law}

Courts will follow a four-stage $\operatorname{process}^{13}$ to establish the applicable law. However, the court will not mechanically move from one stage to the other. ${ }^{14}$ The court seized with the matter will firstly establish whether it has jurisdiction and will secondly characterise the matter. This sequence is not always followed and in some instances courts have first characterised the issue and only afterwards decided the question of jurisdiction. ${ }^{15}$ The third stage would be to consider connecting factors between the matter as characterised and legal systems that could possibly be applicable. ${ }^{16}$ The lex causae (applicable law) will be that of the country to which the connecting factors point. In section 2.3 I

$9 \quad$ Pretorius v Pretorius 1948 (4) SA 144 (O) 149.

10 Forsyth Private International Law 69.

$11 \mathrm{Eg}$ the Hague Conventions initiated by the so-called universalists to unify the rules of Private International Law of different countries; the Rome Convention on the Law Applicable to Contractual Obligations of 1980 and the Brussels Convention of 1968 on jurisdiction and the enforcement of judgments in civil and commercial matters (Forsyth Private International Law 51-52).

12 Forsyth Private International Law 9.

13 Ibid.

14 Ibid.

15 Parry v Astral [2005] 10 BLLR 989 (LC) 999-1004.

16 Forsyth Private International Law 10. 
will discuss the situation where these connecting factors point to more than one country. The fourth stage would be the ascertainment of the content of the lex causae. $^{17}$

\subsection{Assuming jurisdiction}

For the court to assume jurisdiction, two requirements must be met. Firstly, there must be a ratio jurisdictionis (ground of jurisdiction or a cause of action) between the matter and the area where the court has jurisdiction. The contract must for example have been concluded or performed within the area of the court's jurisdiction or breach of contract must have taken place in this area. ${ }^{18}$

Secondly, the defendant must be domiciled or resident within the court's jurisdiction for the judgment to be effective. He/she must be an incola (domiciled or resident in the area) of the court and not a peregrinus (foreigner). However, the requirement of effectiveness will be satisfied if the defendant is a peregrinus who submits to the jurisdiction of the court. ${ }^{19}$ As far as companies are concerned, the company will be regarded as an incola of the court if it is registered within the court's area of jurisdiction ${ }^{20}$ or if its principal place of business is within that area. ${ }^{21}$ In these instances the doctrine of effectiveness will be satisfied. ${ }^{22}$

17 Forsyth Private International Law 11.

18 Estate Agents Board v Lek 1979 (3) SA 1048 (A) 1062.

19 In American Flag plc $v$ Great African T-shirt Corporation 2000 (1) SA 356 (W) 449 the court held that this would be the case if the plaintiff is an incola. If both plaintiff an defendant are peregrini the court would only have jurisdiction if property of the defendant is attached (Veneta Mineraria Spa v Carolina Collieries 1987 (4) SA 883 (A) 894)

20 Bisonboard v Braun Woodworking Machinery 1999 (1) SA 482 (A).

21 ISM Inter v Maraldo 1983 (4) SA 112 (T).

22 In Nobela $v$ Consulate General USA [1999] 1 BLLR 31 (LC) the court stated that in terms of the Foreign States Immunity Act 87 of 1981, foreign states are immune from the jurisdiction of South African courts but that section 5 of the act does provide an exception in the case of an employment contract. In DeGeorges and Safari Club International (2002) 23 ILJ 952 (CCMA) the commissioner held that the CCMA did not have jurisdiction where the employee was employed by a US entity, since the judgment would not be enforceable against a foreign entity. 


\subsection{Characterisation/classification}

Once jurisdiction has been established, a person's claim must be placed in the correct legal category by the process of characterisation. ${ }^{23}$ The dispute may be about the validity of a marriage, a delictual claim for damages, or a claim for damages arising from an international employment contract with which we are concerned here. Different legal systems may characterise the same dispute differently. The legal rules of the court seized with the matter will usually be applied to characterise the matter. ${ }^{24}$ This is no hard and fast rule, as the rules of potentially applicable legal systems may also be taken into account by the court seized with the matter. ${ }^{25}$

\subsection{Establishing the lex causae (proper law) of the contract}

The rules of private international law will be applied to establish the law that will regulate the matter and the substantive rules of the law of the country identified as the lex causae will then regulate the matter. ${ }^{26}$ As a general rule of private international law, the choice of a legal system by parties to a contract with foreign elements will be respected by the courts. ${ }^{27}$ This allowance for freedom of contract and autonomy of the parties has the advantage of creating certainty in terms of the legal system that will govern the matter. If parties did not make a choice, either explicitly or tacitly, the court will consider connecting factors between the dispute as characterised, and the potentially applicable legal systems. This approach is the so-called objective approach ${ }^{28}$ and is to be preferred to the subjective approach that entails that courts work with the

23 Forsyth Private International Law 69, argues that it is legal rules that are characterised. This is also the view of Booysen $\mathrm{J}$ in Laconian Maritime Enterprises $v$ Agromar Lineas 1986 (3) SA 509 (D).

24 Laurens v Von Höhne 1993 (2) SA 104 (W) 116.

25 Some authorities prefer the via media way of characterising the dispute (Laurens $v$ Von Höhne 1993 (2) SA 104 (W) 116). The law of the lex causae may according to this method of characterising be applied to characterise the matter if this would lead to a more just result.

26 Parry v Astral [2005] 10 BLLR 989 (LC) 997

27 Van Rooyen Kontrak 72-73.

28 This approach was preferred by the court in Laconian Maritime Enterprises $v$ Agromar Lineas 1986 (3) SA 509 (D) 525. 
"presumed intention of parties". ${ }^{29}$ If the dispute is about a breach of contract, the place of conclusion of the contract and the place where the contract was performed are important connecting factors. ${ }^{30}$ These factors may correspond with the connecting factors that the court will take into account when it considers whether to assume jurisdiction.

If there are connecting factors pointing to more than one legal system, the court must have regard to the system to which the dispute, as characterised, will have the most real connection. ${ }^{31}$

Mandatory legislation of a court seized with the matter will apply, in spite of the choice of the parties. ${ }^{32}$ However, choice by the parties will be allowed if the weaker party is afforded more beneficial terms than those in the mandatory legislation. $^{33}$

Furthermore, if the terms of the contract are against public policy of the lex fori (law of the forum seized with the matter), for example unreasonable terms regarding a restraint of trade, or discriminatory terms in an employment contract, this will not be enforced. South African labour legislation, such as the Labour Relations $\mathrm{Act}^{34}$, the Basic Conditions of Employment $\mathrm{Act}^{35}$ and the Employment Equity $\mathrm{Act}^{36}$ could be seen as crystallized public policy that will override the choice of a legal system by the parties if this choice is detrimental to the employee.

29 This approach was followed in Standard Bank of South Africa $v$ Efroiken and Newman 1924 AD 171.

30 Van Rooyen Kontrak 78-100.

31 In Parry v Astral [2005] 10 BLLR 989 (LC) 892 the Labour Court indicated that the test for the most real connection will be a qualitative rather than a quantitative test.

32 Dicey and Morris Conflict of Laws 1307.

33 This is in accordance with a 6 of the Rome Convention on the Law Applicable to Contractual Obligations, 1980. This Convention is not binding on South Africa, but has been taken into consideration by the South African Labour Court.

34 Labour Relations Act 66 of 1995.

35 Basic Conditions of Employment Act 75 of 1997.

36 Employment Equity Act 55 of 1998. 


\subsection{Ascertainment of the content of the lex causae}

In the event that the lex causae is a foreign legal system, expert evidence will be needed to prove the content of the rules of such a system. The court with jurisdiction will then apply these rules to the case. However rules against the public policy of the particular court with jurisdiction, will not be applied. ${ }^{37}$

\section{The influence of the Constitution}

South Africa has constitutionalised the right to fair labour practices ${ }^{38}$, but also other rights that are of great importance to employees such as the right to equality $^{39}$ and the right of freedom of association ${ }^{40}$. Will these rights be applicable to South African employees working in other countries or to foreigners working in South Africa and coming from countries where these rights are not protected? The answer to this question will be found in the influence (if any) of the constitution on the rules of private international law as applied by South African courts.

In this regard, Forsyth, the leading authority on private international law in South Africa remarked as follows:

[T] he constitution has not yet brought about fundamental changes in private international law. This is, because on the whole, the existing law is compliant with the standards of the Constitution. The new constitutional order thus does not dominate but exerts a beneficial influence on this branch of the law. ${ }^{41}$

One could add to Forsyth's 2003 comment that the current rules of private international law already provide the basis for the development of constitutionalism, as it provides for the application of mandatory rules that can be seen as the embodiment of public policy principles.

37 Forsyth Private International Law 11.

38 S 23 of the Constitution of the Republic of South 1996. Hereafter the Constitution.

39 S 9 of the Constitution.

$40 \mathrm{~S} 18$ of Constitution.

41 Forsyth Private International Law 17. 
Furthermore, the courts play an important role in developing constitutional principles. An example of this is that the South African Labour Court has developed the rules of private international law by emphasising the protection of rights in the Constitution. This is in accordance with section 39(2) of the South African Constitution that provides that courts must promote the spirit, purport and objects of the Bill of Rights when developing the common law.

\section{$4 \quad$ The role of the Labour Court}

It is evident from recent judgments of the Labour Court that the court will readily assume jurisdiction and will readily hold that the proper law of the contract is South African law in order to protect the constitutional rights of employees working in or outside South Africa where the matter has a connection with the South African legal system. In contrast to the High Courts, which has inherent jurisdiction, the Labour Court is a creature of statute and may not apply foreign law. ${ }^{42}$ The jurisdiction of the Labour Court turns on two factors, firstly on territorial jurisdiction in the Republic of South Africa and secondly on matters that are specifically assigned to the Labour Court in terms of the Labour Relations Act or any other law.

Three judgments of the Labour Court will be discussed below to highlight the role of this court in protecting the constitutional rights of employees who are parties to international employment contracts.

\subsection{Kleynhans v Parmalat}

In Kleynhans v Parmalat ${ }^{43}$ a South African employee of Parmalat South Africa was seconded to Mozambique to work for Parmalat Mozambique for three years on a fixed-term contract. However, the contract was terminated after only one year. Kleynhans claimed damages for breach of contract from Parmalat SA 
in the South African Labour Court. Parmalat SA contended that they were not the employer and that as the workplace was not in South Africa, the Labour Court had no jurisdiction and the applicable legal system should be that of Mozambique.

The Labour Court characterised the issue as the common law breach of an international employment contract. $^{44}$ In applying the consecutive stages process referred to above, the court decided that it did have jurisdiction in this case. The reason, according to the court was that the parties tacitly chose South African law to be applicable by agreeing in the new contract that terms and conditions would remain the same as previously. The Labour Court further argued that by choosing South African law to apply to the contract, the parties also made a choice of jurisdiction in favour of South African courts. ${ }^{45}$ The court also examined connecting factors to assign the proper law in the event that its conclusion that the parties tacitly chose South African law was wrong. Using the same method and connecting factors for both assuming jurisdiction and finding the proper law, the court found that the proper law was South African law. ${ }^{46}$ This decision was criticised on the ground that processes of finding the proper law and assuming jurisdiction (as indicated above) are totally different and should not be conflated. ${ }^{47}$

According to the court an added reason for assuming jurisdiction was that the employee's constitutional right of access to the court would be protected:

PM [Parmalat Mozambique] is not a party to this case and no one testified on its behalf. If its defence succeeds in Mozambique and this Court declines jurisdiction, the applicant would be without a forum to pursue his claim in terms of the three-year contract. Constitutionally this may be untenable as the applicant may be without a forum to ventilate his dispute. ${ }^{48}$ 
The court seems to add a new ground, never before considered as a reason for assuming jurisdiction. This could be seen as the development of the common law rules of private international law to reflect the spirit, purport and objects of the Constitution. ${ }^{49}$

In contrast to previous decisions of South African courts the Labour Court did not regard the place where the contract was performed as the most important connecting factor in indicating the legal system that should be applicable (proper law or lex causae). The Labour Court regarded the place of performance (in this case Mozambique), as only one of the connecting factors (and no longer the most important) and held that the contract had the most real connection with South Africa. ${ }^{50}$ The court emphasised moreover that the older cases relied on by Parmalat dealt with the interpretation of statutory provisions and not with breach of contract as in the present case. In justifying the reason for holding that South African law is the proper law, the court stated that

If the law of a forum subscribes to international labour and human rights standards it is, in my view, a factor that favours the law of such forum. ${ }^{51}$

The implication is that South Africa adheres to these principles and Mozambique does not. This statement can be criticised as there was no evidence about the Mozambican constitution or the protection of human rights in that country. What is significant is that the court was prepared to assume jurisdiction and make a decision on the proper law of the contract with the purpose of making South African law applicable in order to protect the constitutional rights of the employee.

49 S 39(2) of the Constitution.

50 The approach in Parmalat was followed in Werner/Capital Contracting Services [2005] 1 BALR 138 (CCMA). However, the reasoning in Parmalat that the lex loci solutionis (law of the place where the contract was performed) is but one of the connecting factors as criticised by Fredericks 2006 SA Merc LJ 80, on the ground that it could result in severe lack of certainty. The author prefers an approach in terms of which all factors will be weighed up, but in terms of which the lex loci solutionis should be the most important factor.

51 [2002] 9 BLLR 879 (LC) 890. 


\subsection{Parry v Astral Operations}

In Parry v Astral Operations ${ }^{52}$ a South African citizen worked in Malawi for a South African company. He was retrenched and claimed damages for breach of contract, non-payment of severance pay (in terms of the South African Basic Conditions of Employment Act) and unfair dismissal (in terms of the Labour Relations Act). In the alternative to the last-mentioned claim, the employee also relied on the infringement of his constitutional right to fair labour practices.

The employer argued that the lex loci solutionis was decisive and in accordance with previous decisions of South African courts. ${ }^{53}$ The employer further argued that -

....reliance on the place of work (lex loci solutionis) to determine jurisdiction is logical and sensible because of the prohibition of the extra-territorial application of statutes and the doctrine of effectiveness. $^{54}$

The employer listed certain factors to indicate that the contract was connected to Malawi and disconnected to South Africa.

The court characterised ${ }^{55}$ the dispute as an international employment contract and assumed jurisdiction on the ground that the cause of action, namely breach of contract, arose in South Africa. Thus the requirement of a connecting factor with the area of jurisdiction of the court was satisfied. The requirement of effectiveness of the judgment was satisfied by the fact that the employer company was registered in South Africa. ${ }^{56}$

52 Parry v Astral Operations [2005] 10 BLLR 989 (LC).

53 The respondent relied on cases such as Chemical \& Industrial Workers Union $v$ Sopelog CC (1993) 14 ILJ decided in terms of the Labour Relations Act 28 of 1956.

54 [2005] 10 BLLR 989 (LC) 994.

55 The court first characterised and then moved to the next stage of deciding the question of jurisdiction. According to Forsyth Private International Law 10, the order for the consecutive stages process is the other way around. The stages need however not be followed mechanically. 
The court further stated that the court in Malawi could refuse to assume jurisdiction. ${ }^{57}$ As in Kleynhans, discussed above, it seems as if this is an added reason why the court assumed jurisdiction, namely the protection the employee's constitutional right of access to the courts.

In establishing the proper law the court found that parties tacitly/impliedly chose SA law. This conclusion was based on a clause in the contract that subjects the employee to the "policies of employer". ${ }^{58}$ The Labour Court could perhaps be criticised for reaching this conclusion on the basis of this single phrase without any other evidence of the parties' intention to choose South African law. The court did however state that in the event that it was wrong in deciding that the parties chose South African law, the connecting factors point towards South African law as the most real connection. These connecting factors included that the employee was under the control of the South African employer and that the place of the conclusion of the contract was in South Africa.

The court referred to the role of mandatory legislation and quoted the Rome Convention that provides that the choice of law of parties will be decisive, except if the employee party is less protected than under the mandatory rules that would have been applicable in the absence of choice. ${ }^{59}$ The court stated that although South Africa is not bound by the Convention, the court must consider international law in terms of section 39 of the Constitution and that -

[n]othing in the Convention conflicts with the Constitution or our labour rights and further...guided by the Convention the first enquiry will be to establish that the employee has not been deprived of the protection of mandatory rules. Given the breadth of the mandatory provisions of South African labour legislation, discharging this onus is a hard row to hoe. Added to this is the onus on the party relying on foreign law to prove its contents. ${ }^{60}$ 
The court explained that each country applies its own public law norms and these norms would be automatically regarded as part of the employment contract, in spite of the choice of parties. There was no satisfactory proof of the content of Malawian labour law before the court. The Labour Court therefore held that the mandatory laws of South Africa were applicable.

The court added:

[i]n South Africa, an added consideration is the elevation of labour rights to a constitutional right. In my opinion, the constitutionalisation of labour rights strengthens the public policy and protective components of labour law... ${ }^{61}$

In other words the fact that labour rights are protected in the Constitution is an added factor that points towards the application of the South African legal system.

Had the Labour Court held that the place of performance was still the decisive connecting factor, (as previously decided in some South African cases ${ }^{62}$ ) the law of Malawi could have left the employee without a remedy or in a worse position than under South African law. This possibility seems to be an important reason for holding that the proper law was South African law.

In summary, the court assumed jurisdiction and assigned the proper law as that of South Africa, by emphasising the constitutional rights of the employee and thereby developing the rules of private international law.

\subsection{Moslemany v Lever Brothers}

In Moslemany $v$ Lever Brothers ${ }^{63}$ an Irish employee worked in South Africa for AMET, a division of Lever Brothers which was regarded by the court as a multinational enterprise (MNE). The employee was in danger of being

61 [2005] 10 BLLR 989 (LC) 1000.

62 See Chemical \& Industrial Workers Union v Sopelog CC (1993) 14 ILJ 144 (LAC) and Genrec Mei v ICISEMI [1995] 4 BLLR 1 (AD).

63 Moslemany v Lever Brothers (2006) 27 ILJ 2656 (LC) 2660. 
retrenched and launched an application to interdict Unilever from terminating his employment. Lever Brothers denied that it was the employer and argued that a South African court should in any case not have jurisdiction as both Lever Brothers and the employee were peregrini (foreigners).

The Labour Court referred to the International Labour Organisation's Tripartite Declaration of Principles concerning Multinational Enterprises and Social Policy. The court described the Declaration as a -

...tool for regulating the effects of globalisation on employment, as it is a weapon for holding MNE's and other stakeholders accountable for upholding and promoting the standards set in the declaration.

The court further stated that -

MNEs should not be allowed to evade liability by blockading themselves with new and evolving forms of corporate entities. ${ }^{64}$

The court added that courts should opt to exercise jurisdiction and overcome procedural issues so that disputes can be resolved substantively as soon as possible.

The Labour Court assumed jurisdiction on the ground that AMET was a division of Unilever and registered in South Africa. The doctrine of effectiveness would thus be satisfied. ${ }^{65}$ The causes of action were found to be the result of the employment which was within the jurisdiction of the court. The court further held that Unilever was indeed the employer.

The court held that it would be unjust if it did not assume jurisdiction and if it did not hold that Unilever was the employer. By taking this stance the Labour Court clearly continued the overriding consideration of protection of employees followed in earlier cases. 
In August Läpple (South Africa) $v$ Jarret \& others ${ }^{66}$ in which there was also a dispute about the identity of the employer, the Labour Court held that the employee could be employed by two employers, the German company which was the holding company, as well as its South African company which was the subsidiary. The court added:

If externally based companies... were led to believe by the courts that they were free to avoid the reach of the LRA by merely resorting to the simple stratagem of contractually providing that persons (who are clearly employees within the meaning of the very widely defined word "employee" in the LRA) are not employees of internally based subsidiaries, there would be complete and total disadvantage to South African citizens working for these foreign companies....I cannot agree that that is an interpretation of the law that is fair and just. $^{67}$

The overriding effect of protective South African labour legislation is clearly illustrated by this judgment.

\section{Conclusion}

In the globalisation context the Labour Court has contributed to constitutionalism by developing South Africa's common law rules of private international law to afford constitutional protection to employees involved in international employment contracts. This finding suggests that, in dealing with cases that arise in the globalisation era, the courts of all countries have an important role to see to it that the possible negative impact of globalisation on human rights are countered by developing the law to reflect constitutional values. The balancing of the interests of individual employees and those of enterprises (which arguably impact on the economic prosperity of developing countries), remains a challenge. 


\section{Bibliography}

Anon Sunday Times 1

Anonymous "South Africans feared dead in jet crash" Sunday Times 6 May 20071

Cachalia et al Fundamental Rights 3

Cachalia A et al Fundamental Rights in the New Constitution (Juta Cape Town 1994)

Calitz 2000 South African Journal of Economics

Calitz E "Fiscal implications of the economic globalisation of South Africa" 200068 (4) South African Journal of Economics 564-606

Currie and De Waal New Constitutional \& Administrative Law Currie I and De Waal J (eds) The New Constitutional \& Administrative Law Vol 1 (Juta Landsdowne 2001)

Dicey and Morris Conflict of Laws

Dicey AV and Morris JHC (eds) The Conflict of Laws $13^{\text {th }}$ ed (Sweet \& Maxwell London 2000)

Forsyth Private International Law

Forsyth C Private International Law $4^{\text {th }}$ ed (Juta Cape Town 2003)

Fredericks 2006 SA Merc LJ 80

Fredericks EA "The Proper Law of the International Contract of Employment" 200618 SA Merc LJ 75-80

Roodt 2003 SA Merc LJ 135

Roodt C "Jurisdiction in the South African Labour Court: Employer Identity" 200315 SA Merc LJ 135-149 
Van Rooyen Kontrak

Van Rooyen J Die Kontrak in die Suid-Afrikaanse Internasionale Privaatreg (Juta Cape Town 1972)

\section{Register of Legislation}

Basic Conditions of Employment Act 75 of 1997

Constitution of the Republic of South 1996

Employment Equity Act 55 of 1998

Foreign States Immunity Act 87 of 1981

Labour Relations Act 66 of 1995

Labour Relations Act 28 of 1956

\section{Register of cases}

American Flag plc v Great African T-shirt Corporation 2000 (1) SA 356 (W)

August Läpple (South Africa) v Jarret \& others [2003] 12 BLLR 1194 (LC)

Bisonboard v Braun Woodworking Machinery 1999 (1) SA 482 (A)

Chemical \& Industrial Workers Union v Sopelog CC (1993) 14 ILJ

DeGeorges and Safari Club International (2002) 23 ILJ 952 (CCMA)

Estate Agents Board v Lek 1979 (3) SA 1048 (A)

Genrec Mei $v$ ICISEMI \& others [1995] 4 BLLR 1 (AD)

ISM Inter v Maraldo \& Another 1983 (4) SA 112 (T)

Kleynhans v Parmalat [2002] 9 BLLR 879 (LC)

Laconian Maritime Enterprises Ltd v Agromar Lineas Ltd 1986 (3) SA 509 (D)

Laurens v Von Höhne 1993 (2) SA 104 (W)

Moslemany v Lever Brothers (2006) 27 ILJ 2656 (LC)

NK v Minister of Safety and Security (2005) 26 ILJ 1205 (CC)

Nobela $v$ Consulate General USA [1999] 1 BLLR 31 (LC)

Parry v Astral [2005] 10 BLLR 989 (LC)

Pretorius v Pretorius 1948 (4) SA 144 (O)

Standard Bank of South Africa v Efroiken and Newman 1924 AD 171

Trythall v Sandoz (1994) 15 ILJ 661 (IC)

Veneta Mineraria Spa v Carolina Collieries 1987 (4) SA 883 (A)

Werner/Capital Contracting Services [2005] 1 BALR 138 (CCMA) 


\section{Register of Conventions}

Rome Convention on the Law Applicable to Contractual Obligations, 1980

\section{Register of Internet resources}

Waluchow 2007 http://plato.stanford.edu/entries/constitutionalism/ 7 May

Waluchow W 2007 "Constitutionalism" Stanford Encyclopedia of

Philosophy [Found on internet]

http://plato.stanford.edu/entries/constitutionalism/ [Date of use 7 May 2007]

\section{List of abbreviations}

MNE

multinational enterprise

$\mathrm{S}$

section(s) 